\title{
UNIVERSITYOF
}

FORWARD

THINKING

WESTMINSTER用

WestminsterResearch

http://www.westminster.ac.uk/westminsterresearch

Lesbian and gay teachers and sex/uality education policy enactment in schools

Rudoe, N.

This is an Accepted Manuscript of an article published by Taylor \& Francis in Discourse: Studies in the Cultural Politics of Education, doi:10.1080/01596306.2017.1310085

The final definitive version is available online:

https://dx.doi.org/10.1080/01596306.2017.1310085

(C) 2017 Taylor \& Francis

The WestminsterResearch online digital archive at the University of Westminster aims to make the research output of the University available to a wider audience. Copyright and Moral Rights remain with the authors and/or copyright owners.

Whilst further distribution of specific materials from within this archive is forbidden, you may freely distribute the URL of WestminsterResearch: ((http://westminsterresearch.wmin.ac.uk/).

In case of abuse or copyright appearing without permission e-mail repository@westminster.ac.uk 
Lesbian and gay teachers and sex/uality education policy enactment in schools

Naomi Rudoe

Department of History, Sociology and Criminology, University of Westminster, London, $U K$

Naomi Rudoe

Senior Lecturer, Sociology

Department of History, Sociology and Criminology, University of Westminster, 309 Regent Street, London W1B 2HW

n.rudoe@westminster.ac.uk

02035064652 


\section{Lesbian and gay teachers and sex/uality education policy enactment in schools}

This paper examines lesbian and gay teachers' identities and experiences in schools in the context of school policies relating to homophobia and to sex and sexuality education. Drawing on semi-structured interviews with twelve lesbian and gay teachers working in English and Welsh schools, and using Ball, Maguire and Braun's (2012) concept of 'policy enactment', I analyse the ways in which school policies around homo/bi/trans-phobic bullying and sex/uality education and their enactment are perceived by lesbian and gay teachers. The article examines teachers' personal experiences in relation to sexuality in school, and then broadens out into related issues for pupils and a discussion of the varied approaches to sex and relationships education in the schools. I argue that the enactment of these policies is not straightforward, and that they could be better supported by a more inclusive and comprehensive sexuality education curriculum.

Keywords: lesbian and gay teachers; sexuality education; sex and relationships education; homophobia; policy; school

\section{Introduction}

From the implementation of Section 28 of the Local Government Act 1988, which prohibited local authorities in Britain from 'promoting homosexuality' and from 'the teaching in any maintained school of the acceptability of homosexuality as a pretended family relationship', to the recent government investment in tackling homophobic, biphobic and transphobic (HBT) bullying in schools, Britain has come a long way in terms of promoting LGB equality in education as well as in wider society. The recent passing of the Marriage (Same Sex Couples) Act 2013, and of the Equality Act 2010, making it unlawful to discriminate against employees on the basis of sexual orientation, is indicative of legislative equality for lesbian, gay and bisexual people. However, $22 \%$ of respondents to the 2013 British Social Attitudes survey stated that they thought that 
homosexuality is 'always wrong' (Park, Bryson, Clery, Curtice, and Phillips, 2013). In schools, Stonewall's most recent report (Guasp, Ellison and Satara, 2014) shows that homophobic bullying continues to be a problem, with $86 \%$ of secondary teachers saying that pupils in their school, regardless of sexual orientation, experience homophobic bullying. The legacy of Section 28 endured for many years, even after its repeal in England and Wales in 2003, and its language is echoed in the existing statutory Department for Education and Employment (DfEE) Sex and Relationship Education Guidance for maintained schools, academies and free schools dating from 2000 (issued under New Labour'1), which states that 'There should be no direct promotion of sexual orientation' (DfEE, 2000, p. 13) in schools. As Sauntson and Sundaram (2016) point out, the idea of being able to 'promote' any kind of sexual orientation is highly contested, and the retention of this phrase is inconsistent with more recent legislation and policy. Policy discourses around sexuality and gender identity have thus been slow to change and to keep pace with the realities of lived experience.

This paper is concerned with lesbian and gay teacher identities and experiences in school, and uses Ball, Maguire and Braun's (2012) concept of 'policy enactment' to analyse the ways in which school policy and teaching in relation to sexuality and gender as well as to tackling homophobia, biphobia and transphobia, are perceived by lesbian and gay teachers. Drawing on Ball et al (2012), the key idea is that policies are indeed enacted, rather than implemented, in a subtle and inchoate, sometimes messy and often contested process. Teachers in different positions (for example, relating to level of responsibility or experience) will have various relations to policies that always need to be examined in the material context of the school. Policies have to be "put "into"

\footnotetext{
${ }^{1}$ The period of Labour Party government from 1997-2010 under Tony Blair and Gordon Brown.
} 
practice...with the resources available' (Ball et al., 2012, p. 3); the concept of 'resources' here may relate to time, depth of experience, training or school ethos. Working with this nuanced understanding of policy enactment is useful for understanding the complexity of the subject position of the lesbian or gay teacher, who may or may not be open about their sexuality in school, and whose position in a particular school may influence their identity management and relationship to policy. As Maguire, Braun and Ball (2015, p. 487) state, 'depending on the perspectives, values and positions of different types of policy actors and different types of policies, as well as grounded factors of time and place, enactments are contingent, fragile social constructions'. These ideas are also useful for recognition of the concept that differently positioned teachers may or may not wish to bring any personal identity narrative into school, or may not feel comfortable with being 'the gay teacher' without the context of a whole-school approach to the welcoming of gender and sexual diversity.

The paper uses the narratives of lesbian and gay teachers to discuss policy enactment and to examine three areas that are relevant to policy on sex/uality education: lesbian and gay teachers' experiences relating to sexuality and identity in school, the teachers' experiences of homophobia and sexism in their schools, and their perspectives of sex and relationships (SRE) policy and teaching in their schools. This leads to a discussion of some wider implications arising from these areas of focus.

\section{Lesbian and gay teachers in school}

Previous research has examined lesbian and gay teachers' experiences in schools in the UK and Australia (Ferfolja, 2008; Ferfolja and Stavrou, 2015; Gray, Harris and Jones, 2016; Rudoe, 2010; Rudoe, 2014). Recent research in Australia has demonstrated that 
while some schools are creating a more positive climate for lesbian and gay teachers, there is much more to be done at a structural level (Ferfolja and Stavrou, 2015). Gray et al (2016), in a study in Victoria, Australia, found that while some teachers were able to disrupt heteronormative understandings in their schools, LGBTQ issues were still being addressed within reactive paradigms, due to homophobia, rather than being made part of a 'real social justice agenda' (p. 299). Comparative research with lesbian and gay teachers in California and Texas (Connell, 2012) found that while state- and schoolwide legal and policy protections were important, the relative gay-friendliness of the school environment was crucial; Connell shows how the local school context shapes teachers' decision-making processes in terms of being 'out' in school.

While focusing on whether lesbian and gay teachers are 'in' or 'out' at school is a useful starting point, it is crucial to take a broader approach that recognises the limits of an 'in/out' dichotomy and of the issue of teachers being potential 'role models' for pupils (see Russell, 2010). Teachers (gay or straight) may consider their sexuality irrelevant to their professional identity and may not wish to mention their partner in front of pupils. A focus solely on identity management of lesbian and gay teachers removes the onus on all teachers, and on schools collectively, to work to create an environment that welcomes gender and sexual diversity. As a lesbian teacher writes in

\section{The Guardian:}

what we also need is for heterosexual members of staff to shout the loudest. We need them to display Stonewall posters, openly refer to gay friends and relatives, remove the stigma of discussing sexuality - because they recognise that, despite the legalisation on gay adoption and gay marriage, facing your sexuality can be hard - for staff as well as students.

(Skinner, 2015)

Additionally, it is useful to think 'queerly' in terms of an avoidance of binaries

('in'/'out'; gay/straight), and of sexuality as plural and in process, rather than as fixed 
and immutable (Barker and Scheele, 2016). This also relates to a more sophisticated approach to sexuality education curriculum, as I will discuss later.

\section{Policy matters}

I am working here with a broad concept of 'policy' in relation to sexuality and education. At the broadest level, I am interested in government policy on sex and relationships education and on addressing HBT bullying in schools, and then in how this filters down into school-level policies which lay out what will be covered in their SRE curriculum and how they will address matters relating to gender and sexual diversity in the school, and then in how these school-level policies are perceived and responded to by individual (in this case, lesbian and gay) teachers.

In spite of attempts over the past decade to make sex and relationships education compulsory in all schools, and of New Labour's intention to do so (efforts failed prior to the general election of 2010 , at which Labour lost power), the situation remains complex, and it is difficult to ascertain the full extent of SRE teaching in primary and secondary schools in England. The government states that all schools should teach Personal, Social, Health and Economic Education (PSHE) (which includes SRE), but SRE is statutory only in (local authority-) maintained secondary schools. Given that academies and free schools (funded directly by the government) currently constitute just under two thirds of all secondary schools in England, this means that SRE is compulsory only in around one third of secondary schools. However, academies and free schools (as well as maintained schools) must all demonstrate to Ofsted ${ }^{2}$ their

\footnotetext{
2 Ofsted is the Office for Standards in Education, Children's Services and skills, a non-ministerial government department that inspects and regulates education and childcare services.
} 
promotion of pupils' spiritual, moral, social and cultural development (Ofsted, 2016). Maintained schools have a legal duty to teach SRE at key stages $3 \& 4$ (age 11-16), including teaching about reproduction, sexuality and sexual health. While the extent and quality of SRE teaching across all schools is difficult to assess, Ofsted (2013), following inspection of 50 maintained schools and an online survey of 178 young people, found that SRE required improvement in over a third of schools.

In 2015, the Education Select Committee recommended statutory status for SRE in all primary and secondary schools. However, Nicky Morgan (at the time, Secretary of State for Education) responded that the government had an expectation that schools make provision for SRE, that making it statutory would do nothing to tackle the quality of its provision, and that their immediate focus would be on improving its quality (Morgan, 2016). The government did endorse supplementary advice to the SRE Guidance of 2000, produced in 2014 by Brook, the PSHE Association and the Sex Education Forum, which states that schools have a duty to provide SRE teaching that is accessible to all pupils, including those who are LGBT, and that it should tackle all types of prejudice, including homophobia. The language used to talk about sexual orientation in this document breaks from the SRE Guidance of 2000, in which homosexuality is implicitly discussed as an issue to be 'dealt with' and certainly not 'promoted'.

Ofsted's 2016 School Inspection Handbook states that inspectors will consider the way schools promote respect for different sexual orientations and different families. The Department for Education offered schools a $£ 2$ million package to help them tackle HBT bullying in 2014; eight organisations including Stonewall were given a slice of 
this funding in order to support their projects in this area. An evaluation of these programmes by NatCen (Mitchell, Kotecha, Davies, Porter, Kaxira and Turley, 2016) found that they were successful in improving school staff capacity and confidence to tackle HBT bullying among the participants.

The government is also making some steps towards recognising the extent of the problem of sexism in schools. In 2016 the government's Women and Equalities Committee launched an inquiry into sexual harassment and sexual violence in schools, and compulsory SRE with a whole-school approach was a key recommendation heard in the oral evidence given (House of Commons Women and Equalities Committee, 2016b). Research has pointed to, for example, the increasing sexual commodification of girls' bodies online as a crucial gender equity issue, necessitating finding ways to intervene into the curriculum in order to help young people to negotiate their experiences at school (Ringrose, 2010). Mayo (2014) points out that sexism is not fully addressed in schools and that "new forms of sexism against young transwomen overlap transphobia and misogyny' (p. 93). As Gill (2011) argues, there is a need to think about sexism in the context of other axes of power and difference, including homophobia. The lack of this kind of intersectional, holistic thinking in SRE policy and practice, and its varying levels of existence and quality in schools across Britain, are part of the driving force for this research. There is also a lack of research focusing on teachers' (as opposed to pupils') experiences of gender and sexual diversity in schools.

\section{Methods}

I conducted semi-structured interviews with twelve lesbian and gay primary and secondary teachers in England and Wales during 2015 and 2016. The teachers were recruited using a snowballing method from my personal and professional networks (for 
example, from my university LGBTQ staff network, of which I am a member), and four of them were known to me prior to the research. The teachers ranged in age from early twenties to late forties. I attempted to recruit participants identifying as bisexual, transgender and queer, but this proved difficult. In other respects the sample is diverse, however: the participants teach at a wide range of types of school, and have a varied range of experience:

\begin{tabular}{llll}
\hline Participant & Years teaching & Type of school & Location \\
\hline Amanda & 2 & Primary & Rural area, England \\
Ben & 10 & Secondary free school & London \\
Beth & 20 & Secondary academy & Rural area, England \\
Caroline & 5 & University Technical College & South East \\
Deborah & 11 & Secondary (Jewish) & London \\
Hannah & 10 & Secondary academy & Inner London \\
James & 6 & Secondary community & Rural area, Wales \\
Matt & 7 & Secondary (Catholic) & Outer London \\
Rob & 10 & Secondary community & Inner London \\
Sarah & 28 & Secondary academy & Inner London \\
Sebastian & 15 & Primary & Outer London \\
Tomas & 4 & Secondary academy & Inner London
\end{tabular}

The interviews were transcribed, subjected to open inductive coding, and then to a thematic analysis (Braun and Clarke, 2006). A draft of this article was shared with participants via email, inviting their feedback, in order to enhance validity. All participants have been allocated pseudonyms. Some details of the types of school and location have been omitted in order to retain complete anonymity. The secondary teachers taught a range of subjects including Art, English, History, Music, PE, Physics and Maths. Sarah and Tomas were colleagues and taught at the same school. One limitation of this study was that, while most of the participants had taught SRE, they were, understandably, not able to give a comprehensive overview of the SRE teaching in their school (although one exception to this was Rob, who was a member of the school's Senior Leadership Team). I also did not have access to any policy documents for any of their schools. This paper therefore does not attempt to provide detailed 
analysis of specific policies in schools, and discussion of policy and its enactment is reliant on teacher narrative alone.

\section{Policy enactment}

Ball et al's (2012) study of 'policy enactment' in four secondary schools does not focus specifically on policies relating to SRE, but it does draw attention to the complex and messy aspects of putting policy into practice; it examines teachers as both policy subjects and policy actors. The study highlights that, in the midst of vast numbers of policies and imperatives that schools have, the 'master' discourse is that of performance and student behaviour. It is this that drives policy enactment and takes precedence in schools, even though schools and teaching relationships cannot be reduced to policy ( $\mathrm{p}$. 145). This is partly what renders it challenging for schools to take a holistic and embedded approach to sexuality education, and to issues of gender and sexual diversity and of sexism. While the importance of tackling HBT bullying cannot be doubted, focusing on this in isolation, without attention to wider curriculum and policy, is limiting (Formby, 2015).

The teachers in my study had no trouble in confirming school policy as nontolerant of homophobic bullying:

Homophobia is covered in the bullying policy that we have and it is ...given the same importance as a student being racist. [Sarah]

The head's done quite a few assemblies saying that any bullying or homophobic comments won't be tolerated. [Sebastian]

The unacceptability of homophobic bullying was something that was taken for granted in school policy. Schools certainly took action against it and in response to it, but the existence of anti-homophobic bullying policy does not automatically or easily translate 
into practice or into a prejudice-free environment, as I will demonstrate in the following sections.

Examining the complexity of policy enactment in relation to the data, one theme

that emerged was a lack of general awareness of school policies:

I think it's not so much people's awareness of the [homophobic bullying] policy; I think it's people's ethics ... I suppose it [tackling homophobic bullying] comes from staff's own cultural awareness, really. [Hannah]

I'm not sure that policies would have that much impact on the day to day anyway...I don't think anyone does [read policies]. I don't think they say very much. They'll be documents that sit somewhere, but the way people go about things won't necessarily be informed by them. ... You can only fit so many things into staff meetings every year. Staff constantly changing. A behaviour policy that people know how to use is really important. An SRE one is quite a developing area, it's not compulsory. ...I don't think making it compulsory would make it any better. It would still be inconsistent. ...The trouble with compulsory SRE is that there isn't the infrastructure to do it well. ...the government can't do anything about what goes on day to day in most schools; there is not that level of control. [Ben]

Ben here directly echoed the idea, as cited earlier in relation to Nicky Morgan, that government making SRE statutory would do nothing to tackle its quality (at a macro level, then, the mere existence of a policy would not impact on its implementation). One counter-argument to this is that making it compulsory would give 'official' weight and recognition to its importance. The above extracts give rise to questioning the relationship between written school policy and action. Teachers may not be aware of the content of policies, and the act of a teacher reading the school's homophobic bullying policy may - or may not - have an influence on how they respond to it.

\section{Sexuality and Identity}

All twelve teachers described being open or 'not closed/hidden' about their sexuality with their colleagues at school. Only one participant - Ben - described being open with pupils about the fact that he was gay:

The kids - I hadn't said anything to any of them until this day a year ago when we had a sex education day. Someone asked, and I said then. And since having said that, I won't 
sort of drop it into conversation very much. ... it's easier to bring it up if the children are being homophobic, which is the other time that I'd mention it. ... I'd talked with one of my friends quite a lot before I did this SRE day about what I'd do if someone asked me. We talked about how important it is for people to know gay people. That that is the thing that has turned it around for us in the past 50 years. As more and more people become openly gay, less and less people hate.

In several other cases participants reported that some of their pupils knew they were gay but it wasn't something they explicitly discussed with them. In most cases, however, teachers were not 'out' to their pupils. Sometimes this was because they felt that they would not reference or discuss their personal lives with pupils whether they were gay or straight, but others expressed concern around being 'treated differently' as a result of their sexuality. This sometimes emerged in the context of my asking whether they would be more open with pupils if they had an opposite sex partner (which I asked in order to ascertain if participants felt they needed to hide an aspect of themselves owing to their sexuality):

I don't know, I think depending on which kid it was who was asking, if I were married to a man I might well have told them a bit more....I don't know. I suppose it's a fear. The fear that they'll, erm, [pause] that they'll treat you differently. [Hannah]

When I was an LGBT youth it would have been nice to have had someone, not as a role model necessarily, but just to know that there are people who are gay, it's fine...I had considered, because I was at one point about to leave the school... at least then I should come out, maybe do an assembly on homophobia...it's not that I'm worried about bullying...it's just that it just makes my life easier, if that's not another thing that I have to deal with....Even though they're children it's still not nice being treated differently by them. [Tomas]

There was a general reticence and sometimes a nervousness around being open with pupils, especially since this broadens the issue to the wider community of parents. Two of the teachers mentioned the fact of their working in a faith school as a concern, and Amanda also described dealing with taking over from a previous colleague who had been very popular:

Given the school's Church connections, I didn't come out to...staff until I'd accepted the post...I've never come out to my pupils, but I wish I had....as a new teacher in the school I had already fought really hard to win the confidence of the parents. My predecessor - an experienced male teacher - had been idolised by the parents and pupils, and many were extremely disappointed not to be taught by him when he left. Rightly or 
wrongly, I didn't want my sexuality to be held against me before I felt I had all parents on side.

Rob had a younger colleague who had come out to pupils at the school:

$[\mathrm{He}]$ did actually tell his form class, and I wondered if I should do the same, but it did create a few issues. ... Maybe that's a kind of generational thing ... being 10 years younger... he's also a bit of an activist - that's something I never was... I remember feeling quite guilty, that maybe I had a duty and so did my other [gay] colleagues, to support him by doing the same. We went out for a drink and had a long conversation about it and ultimately we came to the decision that it's a personal choice.

The fact that teachers felt able to talk about their same sex partners with colleagues, however, represents a positive move away from the closeted era of Section 28, which cast a shadow over issues around sexuality in schools. There has been a distinct change from the silencing of lesbian and gay sexualities in school reported around the time of the repeal of Section 28 (see Epstein, O'Flynn and Telford, 2003). Civil partnerships and marriage have provided increased recognition for same-sex couples. Neary (2014) points out that the introduction of civil partnerships provided 'legitimacy' and confidence for lesbian, gay and bisexual teachers when negotiating their school contexts (while recognising the problematic legitimate/illegitimate dichotomy this invokes). As Hannah commented:

I think my mentality's changed. I'm much more open about being gay now than I was when I first started. ...it's changed in that there's more awareness about homophobia as a problem, which I suppose correlates with gay marriage, and all of the stuff in the press.

Policies around homophobic bullying from New Labour onwards and schools' work in this area have also contributed to a significantly different environment in schools currently compared to thirty years ago. Policy enactment in this area, then, has been 'successful' to a certain extent, as will be demonstrated in the following section.

Most of the secondary school teachers were aware of pupils who openly identified as gay or lesbian in school, and in many cases the teachers were not aware of any negative issues or experiences in school for these pupils: 
There are a number of sixth form girls, probably five or six that are openly lesbians ... it's accepted in the sixth form and it's accepted I think throughout the school. [Sarah]

Certainly in the sixth form we've got pupils coming out, and they've had a really positive experience. The one issue that we had was with a Bengali boy that came out, and that created tensions amongst the Bengali students for obvious reasons - religion, culture and so on. [Rob]

Some were aware of pupils who did not identify with their biological sex or had transitioned, and this had elicited varying responses from the school. Deborah gave the example of a year 7 (age 11-12) girl in her school who looked like a boy and did not want to tuck her shirt in because it made her feel uncomfortable with her developing body; school staff had been instructed to allow her to wear her shirt without tucking it in. Rob described a student who transitioned from female to male at the beginning of the sixth form:

The sixth form [staff] gave a huge amount of support for him to navigate the NHS and the treatments that were available ... and they still are supporting him - he's...now getting a degree.

However, James commented on a pupil in a school he'd worked at previously who began to identify as a boy, but 'the school's attitude was that they were quite reluctant to call him by his chosen name, and they were equally reluctant to use gender pronouns that fit his choice'. These varying experiences were reflected in differing accounts of prejudice in the schools, as is explored in the following section.

\section{Homophobia and sexism in school}

The prevalence of homophobia in British schools has been widely noted (Guasp et al., 2014; Formby, 2013), although Stonewall has reported a significant decrease in homophobic bullying and language in schools in recent years: in 2014 only $36 \%$ of teachers reported hearing 'that's/you're so gay' often or very often, compared to $58 \%$ in 2009 (Guasp et al., 2014). This change could be put down to the enactment of schools' anti-homophobic bullying policies. It is interesting to look at the school as a workplace, 
and to consider it in the context of a study by Einarsdottir, Hoel and Lewis (2015) examining anti-homosexuality in the British workplace (the authors use this term instead of 'homophobia', in order to capture the broader structural nature of the issue that goes further than derogatory remarks). They found that, in studying six organisations, anti-homosexuality was indirect and hard to pinpoint, with LGB interviewees reluctant to label colleagues as homophobic. They point to the "protective legislation and powerful organisational discourses promoting fairness and equality' meaning that 'exposure to homophobia at work is relatively rare in the British workplace, and generally manifests itself in indirect ways' (p. 1194). What makes a school a unique workplace context is that while protective legislation and policies are in place, the behaviour of young people can be unpredictable and challenging, the quality of the teacher-learner relationship is crucial in order for learning to take place, and the overall culture and curriculum of a school will have a large influence on heterosexist or homophobic attitudes and behaviour.

Teachers generally felt that staff were attuned to homophobia amongst pupils, were well equipped to tackle it, and dealt with it appropriately. Almost all the teachers in the study observed that the pejorative phrase 'that's so gay' was either not something they heard any more, or they heard it much more rarely than in the past:

There used to be a lot of homophobic language but that has really stopped now. Like everything was 'oh it's so gay'... but we had a big clamp down on it... it seems to have worked. [Beth]

Ben reported that 'one student in my tutor group will occasionally use it as an insult. He'll say "you're so gay" to someone else... [though] not to someone who's gay'. However, some of the teachers referred to more specifically 'targeted' incidences of homophobia. James had been called 'bender boy' in a corridor, an incident that he said had been 'dealt with actually very robustly by the school'. Tomas had been called 
'faggot' by a pupil, who was removed from the classroom and excluded from school for four days. In a separate case involving a different pupil, Tomas had been walking down the street holding hands with his boyfriend, and a former pupil (who had, when at the school, called him 'fairy' on several occasions) walked past and called him 'patsy man', an incident that he reported to the police.

Some teachers reported that they heard negative remarks about homosexuality in lessons (which they challenged):

When you teach Nazi Germany and you teach about the Night of the Long Knives, and you tell them about Röhm, who was gay, and allegedly found in the bed of a man when Hitler went to arrest him, sometimes that leads to some 'oh that's disgusting - in the bed of a man, with Hitler' sort of thing, just the bizarre connotation that it's awful because Hitler found him in bed with a man, whatever. [Hannah]

Homophobia from other staff was virtually non-existent, but certainly present in terms of some pupils in some of the schools. Caroline commented that there was 'definitely a group of [year 11] boys who are homophobic' in her school. Rob similarly commented: 'we've had some issues of homophobic bullying ... It's been dealt with openly and effectively'.

A particularly striking theme to emerge from the data was that several teachers commented that sexist and misogynist behaviour or attitudes was a more serious problem than homophobic behaviour in their school. Deborah talked extensively about it:

Sexism is huge ... There are some really confident girls but it takes a lot for them to stand up.... Last year some sixth formers set up a gender equality group ... it was massively supported by the school, and boys went as well as girls, but girls led it ... But it just feels like there's still, the very progressive gender equality group, but the majority of the school is like, oh, what do we need that for? Why are we still talking about it? ... I think there's a lot more sexism than homophobia. Because I think kids are scared, they know they'll be punished for being homophobic, whereas sexism is so pervasive, you can get away with it a lot more easily.

Matt, who worked in a boys' school, similarly said:

It's bad, really bad, like really bad, it's horrific, like some of the things you hear them say ... like they say 'oh no I broke up with my girlfriend because she wouldn't sleep 
with me' ... boys will be showing each other videos of them, like girls performing oral sex on them and you're like 'right, have you, has that girl given you permission?' ... it is a massive, yeah it's a massive problem.

Ben's school had sought to address the issue with input from The Tender Project, a charity working to promote healthy and respectful relationships:

We have lots of problems with the way boys treat girls. We have a real problem in year 10 with some very deeply held misogynistic views...we've gone to great lengths to...try and do something about them.

Issues around sexuality and gender are intricately linked: the ideas that girls and boys should behave in particular ways or are biologically expected to behave in stereotypical ways - be that to be sexually attracted to the opposite sex or to perform certain social or sexual roles, or to identify in terms of binary gender to begin with - remain heavily ingrained, and the issue of sexual consent remains particularly problematic for young people. This illustrates "why SRE cannot be taught in a vacuum but needs to be rooted in discussions of wider social inequalities between women and men, [and] how these play out in expectations of sexual behaviour' (Coy, Kelly, Vera-Gray, Garner and Kanyeredzi, 2016, p. 93). The continuing problems with homophobia and sexism in schools demonstrate why policies on their own are insufficient, and why better SRE teaching in many schools is needed.

\section{SRE teaching in the schools}

The participants gave their personal perspectives on SRE teaching in their schools; most of them had taught some SRE at some point, either as a form tutor or as part of a wholeschool SRE day. The nature and extent of provision in the secondary schools was extremely varied. Some schools used a mix of internal and external provision:

Deborah's school, like Ben's, made use of an external organisation - they employed Streetwise, an organisation providing SRE to Jewish schools, for some sessions. Sarah and Tomas' school had won a national award that had recognised the school's excellent 
SRE teaching. Some schools had a bare minimum of time devoted to SRE: Hannah's

school had a sex and relationships education day once a year:

It's just about contraception, sex, what it means to be in a meaningful relationship, which I suppose is the closest you can come to looking at a gay relationship, but it's couched in terms of a generic relationship. And inevitably that goes into straight relationships - so the boy shouldn't rush a girl into sex, the boy should respect the girl, and that sort of thing. But no there's no explicit addressing of homosexual relationships. ... I can't see that [regular PSHE programme] happening any time soon. The school are too focused on literacy.

James had never taught SRE in any of the schools he had worked in, but he commented

that his experience in his current school was that SRE was taught by:

Literally anybody, and my feeling is from the way that my colleagues talk about it, it's a resented hour on their timetable, they're not particularly bothered about delivering it, they don't know much about the subject, they haven't the time ... The whole PSE, RE, Humanities, does tend to get pushed down. Schools I've worked in, we were just working to get students over that [grade] boundary, that's where all the effort and energy goes.

Beth was quite positive about the SRE in her school, noting that 'same sex partnerships are being discussed', and that it was given one hour a fortnight on the timetable, taught by PSHE teachers, which was an improvement on it previously being taught by form tutors. Rob gave a full description of his school's SRE provision, which was also inclusive of same sex sexuality:

SRE is part of the C[itizenship]PSHE curriculum and it's taught by form tutors and they have an hour of it a fortnight. ...We made the decision to really protect the time.

...We've got a CPSHE coordinator with teachers responsible for each key stage. ... So years 7 and 8 it focuses on puberty and on...emerging sexuality; to understand feelings you might be beginning to have, that kind of thing. As they go into years 9, 10 and 11, the shift moves onto relationships and how to navigate those, and identity ... And in the sixth form, it's looking at those same themes, but looking at the pressures young adults can feel as they begin to navigate all of that. ... It's compulsory for all sixth formers to attend.... It's all done through a process of consultation with form tutors and with the student leadership teams of those different year groups.

In contrast to this, Caroline's school (the University Technical College) provided no SRE at all ('my school would only do more if it met an Ofsted criteria'). Matt commented that 'I know for a fact that ...if we become an academy where we control our own curriculum, there'll be no more PSHE'. The extent of PSHE/SRE provision in 
this small sample of secondary schools, then, was extremely varied - from one hour per fortnight to none at all.

In these narratives it is possible to identify competing targets and initiatives: the pressure around raising achievement/standards can be seen as in conflict with initiatives to tackle sexual and gender inequalities (as discussed earlier in relation to Ball et al (2012)). Finding time in the timetable and ensuring high quality teaching are two key problems in relation to comprehensive SRE. Lack of training, and lack of emphasis on inclusive and relationship-focused SRE are also significant issues (Thomas and Aggleton, 2016). Placing SRE in the hands of teachers who may be untrained and/or reluctant to deliver it implies a leap of faith that it will be done well. As James commented, 'one of the things that I think is wrong is how often teachers are required to do things for which they're not trained or qualified'. A focus on policy and policy enactment is also relevant here. Policies on what is taught in the SRE curriculum in schools will vary, as will their enactment, depending on who is delivering them. Individual teachers committed to high quality SRE teaching and a responsive and inclusive ethos in this area may be working with little institutional support, and conversely, having comprehensive policies on paper does not automatically equal their simple translation into practice.

\section{Discussion}

The previous analysis indicates that both the existence of a policy and care with its enactment are necessary. The content of policies needs to be evaluated in the context of training needs and of a holistic, school-wide approach to teaching about sexuality and gender. Policy relating to the experiences and treatment of LGBT people can be supported by curriculum that addresses diverse sexuality and gender identity and that 
recognises the rights of young LGBT people to SRE that is relevant to them. Issues of what can be agreed on to be 'age-appropriate' SRE for young people may be difficult to resolve. Schools may be concerned with negative parental reaction to SRE, although recent research (Aldlred, Fox and Kulpa, 2016) suggests that increasing parents' understanding of school curriculum and approach to SRE is a positive step forwards. Making SRE a statutory subject would be a crucial step forwards, however, and could still allow for the determination of specific policy and curriculum at local levels. Sexuality education in schools could better encompass concepts of the fluidity of sexuality and gender, questioning the notion of sexual orientation and gender identity as fixed and essentialised. School-based sexuality education also needs to emphasise respectful relationships and consent. The issues of homo/bi/trans-phobia are interlinked with those of sexism and sexual harassment, and statutory SRE would provide the groundwork for serious commitment to tackling them.

In terms of the wider implications of themes arising from this study: this paper has been able to touch only briefly on issues of sexism and gender identity, but both are crucial to any discussion of policies that address sexuality. In particular, more research needs to be carried out into the experiences of trans-identified teachers. No academic studies have been conducted with multiple trans teachers - Harris and Jones' (2014) case study of one Australian trans teacher remains unique - although media articles suggest that there are large challenges in the area of trans issues in schools (see Champion, 2016). In 2013, Lucy Meadows, a transgender primary school teacher in Lancashire, committed suicide after her transition. At the inquest into her death the coroner criticised the 'sensationalist and salacious' media intrusion she had faced (BBC News, 2013). While the Equality Act 2010 outlaws discrimination in employment on the grounds of gender reassignment (to be considered transsexual and thus be protected 
under the Act, a person does not need to be under medical supervision), the government now recognises that the terms 'gender reassignment' and 'transsexual' are outdated and that the protected characteristic needs to be amended to 'gender identity' (House of Commons Women and Equalities Committee, 2016a, p. 3). Issues of gender identity for pupils, and schools' responses to these, are clearly another area requiring research.

\section{Conclusions}

Schools have come a very long way in tackling and responding to homophobia over the past thirty years, and this is no doubt due to the existence of effective policies which are acted upon collectively, as well as major societal shifts in attitudes. I have discussed the change in lesbian and gay teachers' experiences over time, and the reduction in pupils' use of phrases such as 'that's so gay'. I have argued that there is still some way to go before lesbian and gay teachers (and indeed pupils) feel able to be fully open about their sexuality in school, should they wish to be so. Feeling able to make reference to same sex partners to colleagues but not to pupils, for example, does represent a difference in the experiences of lesbian and gay - compared to heterosexual - teachers. While significant progress has been made since the era of Section 28, and while legislative equality exists, there is still more work to be done, and homophobia in schools is still a problem. Better SRE is needed in order to provide a solid base for HBT bullying policies and for learning about sexuality and gender. Comprehensive SRE would also provide a platform for tackling the urgent issue of sexism in schools.

I have discussed the messy relationship between written SRE and HBT bullying policies and their enactment, and the difficulties with enactment in the context of the wealth of policies schools have and the overriding focus on performance and student behaviour. I have also demonstrated that while there is, in government policy terms, an 
expectation that schools should teach SRE, its local enactment and practice varies hugely. HBT bullying policies need to be supported by curriculum that addresses gender and sexual diversity. If inclusive and comprehensive, compulsory SRE is considered in terms of a government policy, then, as I have demonstrated, consideration needs to be given to local policy enactment, as this is not an easy or straightforward matter. Resources (such as time, and training of teachers) need to be in place in order to give policies the space for enactment, and this also needs to include a greater commitment to the well-being of all pupils and teachers in all schools.

\section{References}

Alldred, P., Fox, N. and Kulpa, R. (2016). Engaging parents with sex and relationship education: A UK primary school case study. Health Education Journal, 75(7), 855-868.

Ball, S., Maguire, M. \& Braun, A. (2012). How Schools Do Policy: Policy Enactments in Secondary Schools. Abingdon: Routledge.

Barker, M. J. and Scheele, J. (2016). Queer: A Graphic History. London: Icon Books Limited.

BBC News (2013). Media criticised over transgender teacher Lucy Meadows' death Retrieved from http://www.bbc.co.uk/news/uk-england-lancashire-22694847

Braun, V. and Clarke, V. (2006). Using Thematic Analysis in Psychology. Qualitative Research in Psychology, 3(2), 77-101.

Brook, PSHE Association and Sex Education Forum (2014) Sex and Relationships Education (SRE) for the $21^{\text {st }}$ Century. Retrieved from http://www.sexeducationforum.org.uk/media/17706/sreadvice.pdf

Champion, M. (2016). This Is What It's Like Being A Transgender Teacher In Britain. Retrieved from https://www.buzzfeed.com/matthewchampion/this-is-what-itslike-being-a-transgender-teacher-inbritain?utm_term=.okvy8aRg3\#.rsqlm7QLN 
Connell, C. (2012). Dangerous Disclosures. Sexuality Research and Social Policy 9, $168-177$.

Coy, M., Kelly, L., Vera-Gray, R., Garner, M. and Kanyeredzi, A. (2016). From 'no means no' to 'an enthusiastic yes': Changing the Discourse on Sexual Consent Through Sex and Relationships Education. In Sundaram, V. and Sauntson, H. (eds) Global Perspectives and Key Debates in Sex and Relationships Education: Addressing Issues of Gender, Sexuality, Plurality and Power. Basingstoke: Palgrave Macmillan.

Department for Education and Employment (2000). Sex and Relationships Education guidance. London: DfEE.

Einarsdottir, A. Hoel, H. and Lewis, D. (2015). 'It's nothing personal': Antihomosexuality in the British workplace. Sociology, 49(6), 1183-1199.

Epstein, D., O'Flynn, S. and Telford, D. (2003) Silenced Sexualities in Schools and Universities. Staffordshire: Trentham Books Limited.

Ferfolja, T. (2008). Discourses that silence: teachers and anti-lesbian harassment. Discourse: Studies in the Cultural Politics of Education, 29(1), 107-119.

Ferfolja, T. and Stavrou, E. (2015). Workplace experiences of Australian lesbian and gay teachers: findings from a national survey. Canadian Journal of Educational Administration and Policy, 173, 113-178.

Formby, E. (2013). Understanding and Responding to Homophobia and Bullying: Contrasting Staff and Young People's Views within Community Settings in England. Sexuality Research and Social Policy, 10, 302-316.

Formby, E. (2015). Limitations of focussing on homophobic, biphobic and transphobic 'bullying' to understand and address LGBT young people's experiences within and beyond school. Sex Education, 15(6), 626-640.

Gill, R. (2011). Sexism Reloaded, or, it's Time to Get Angry Again! Feminist Media Studies, 11(1), 61-71.

Gray, E., Harris, A. and Jones, T. (2016). Australian LGBTQ teachers, exclusionary spaces and points of interruption. Sexualities, 19(3), 286-303.

Guasp, A., Ellison, G. and Satara, T. (2014). The Teachers' Report: Homophobic Bullying in Britain's Schools in 2014. London: Stonewall. 
Harris, A. and Jones, T. (2014). Trans teacher experiences and the failure of visibility. In A. Harris \& E. Gray (Eds), Queer Teachers, Identity and Performativity. Basingstoke: Palgrave Macmillan.

House of Commons Women and Equalities Committee (2016a). Transgender Equality. First Report of Session 2015-16. London: The Stationery Office Limited. Retrieved from http://www.publications.parliament.uk/pa/cm201516/cmselect/cmwomeq/390/3 90.pdf

House of Commons Women and Equalities Committee (2016b). Oral evidence: Sexual harassment and sexual violence in schools, HC 91. 7 June 2016. Retrieved from http://data.parliament.uk/writtenevidence/committeeevidence.svc/evidencedocu ment/women-and-equalities-committee/sexual-harassment-and-sexual-violencein-schools/oral/34251.html

Maguire, M., Braun, A. \& Ball, S. (2015). 'Where you stand depends on where you sit': the social construction of policy enactments in the (English) secondary school. Discourse: Studies in the Cultural Politics of Education, 36(4), 485-499.

Mayo, C. (2014). Conclusion: Extravagance and Equity: Queer Tensions in Education. In A. Harris \& E. Gray (Eds), Queer Teachers, Identity and Performativity. Basingstoke: Palgrave Macmillan.

Mitchell, M., Kotecha, M., Davies, M., Porter, H., Kaxira, A. and Turley, C. (2016). Evaluation of an anti-homophobic, biphobic and transphobic bullying programme. London: NatCen Social Research.

Morgan, N. (2016). Letter to Neil Carmichael, 10 February 2016. Retrieved from https://www.gov.uk/government/uploads/system/uploads/attachment_data/file/4 99338/Nicky_Morgan_to_Education_Select_Committee_-_10_Feb_2016--.pdf

Neary, A. (2014). Teachers and Civil Partnership: (Re) Producing Legitimate Subjectivities in the Straight Spaces of Schools. In A. Harris \& E. Gray (Eds), Queer Teachers, Identity and Performativity. Basingstoke: Palgrave Macmillan.

Ofsted (2013). Not yet good enough: personal, social, health and economic education in school. Manchester: Ofsted.

Ofsted (2016). School Inspection Handbook. Manchester: Ofsted.

Park, A., Bryson, C., Clery, E., Curtice, J., \& Phllips, M. (eds) (2013). British Social Attitudes: The $30^{\text {th }}$ Report. London: NatCen Social Research. 
Ringrose, J. (2010). Sluts, whores, fat slags and playboy bunnies: Teen girls' negotiations of 'sexy' on social networking sites and at school. In Jackson, C., Paecher, C. and Renold, E. (eds) Girls and Education 3-16: Continuing Concerns, New Agendas. Berkshire: Open University Press.

Rudoe, N. (2010). Lesbian teachers' identity and the public/private boundary. Sex Education, 10(1), 23-36

Rudoe, N. (2014). Out in Britain: the politics of sexuality education and lesbian and gay teachers in schools. In A. Harris \& E. Gray (Eds), Queer Teachers, Identity and Performativity. Basingstoke: Palgrave Macmillan.

Russell, V. T. (2010). Queer teachers' ethical dilemmas regarding queer youth. Teaching Education, 21(2), 143-156.

Sauntson, H. and Sundaram, V. (2016). Discursive Silences: Critically Analysing the Presence/Absence of Sexual Diversity in the Sex and Relationships Education Guidande for England and Wales. In Sundaram, V. and Sauntson, H. (eds) Global Perspectives and Key Debates in Sex and Relationships Education: Addressing Issues of Gender, Sexuality, Plurality and Power. Basingstoke: Palgrave Macmillan.

Skinner, L. (2015). When they ask 'Miss, are you a lesbian?', I tell them yes. The Guardian, 16 June 2015. Retrieved from https://www.theguardian.com/education/2015/jun/16/lesbian-teacher-outclassroom-gay-students-school

Thomas, F. and Aggleton, P. (2016). School-based Sex and Relationships Education: Current Knowledge and Emerging Themes. In Sundaram, V. and Sauntson, H. (eds) Global Perspectives and Key Debates in Sex and Relationships Education: Addressing Issues of Gender, Sexuality, Plurality and Power. Basingstoke: Palgrave Macmillan. 